\title{
SOME NOTES ON DIFFUSION OF QANAT
}

\author{
IWAO KOBORI
}

\section{Introductury Remarks}

The origin and diffusion of Qanat has been among the very important topics to have been studied by scientists, mainly by geographers and historians. The interest which has attracted the study might be due to its very wide distribution all over the world and its close relationship to the arid environment. Although several studies on this topic have been published, no definite hypothesis has been widely accepted.

From 1956 on, the author has had the same interest as his forerunners but with some difference in viewpoint. His standpoint is, at first, to observe Qanat in situ in their respective areas and synthesize as much as possible. The elaborate hypothesis of Qanat origin, i. e. the Achaemenid origin, or the diffusion of Qanat by the hand of Arabs or Spanish Conquistadores is fairly interesting, but is supported by little documentation. For example, the introduction of Qanat into Chinese Turkestam, is still a big theme to be resolved, i. e. when this Chinese Qanat, (kan-erh-ch'ing) was introduced from Persia. In the case of Chinese Turkestan, one document places this introduction in the 18th century, the other in the 2nd century B. C. The other example is a Qanat in South America. It is very easy to say that Qanat was introduced by Spanish Conquistandores from the Iberian Peninsula. However, recent archaeological exacavation may reverse this hypothesis from the view point of the Pre-Incaic irrigation culture.

The technique of Qanat construction is about the same in the different regions. It is quite natural to have geologically different aquifers and stratigraphy, and the location of Qanat (for example, on the alluvial plain, of foothills or wadi bed...) has various modifications. In those respects, a simple distribution map of Qanat tells only the geographical areas where we find them. For an analysis of the location we need a more detailed classification.

The knowledge and experience of a Qanat digger (Muqqani in Iran) is formidable. The tools they use for levelling are still very simple. Three-holemeasurement for levelling known since the time of the Sasanian Dynasty is still 
used in some area. The author has tried to get their text-book for the research for water or any other documentary sources, not only in Iran but also in West Pakistan or the Sahara.

However, these efforts have not been satisfied because their traditions are only oral. The heredity of their water finding technique is patriarchal and their residential area is concentrated in a specific oasis. The improvement of construction materials (for example, replacing bricks with cement, as in Morocco or Iran) may facilitate the work of Muqqani and confirm their raison d'etre. The big difference between hydraulic or mechanical tools of water distribution in the Qanat region is found in Iran and adjacent areas and the Sahara. In Iran and adjacent areas water is distributed only on the basis of arranged time. In the Sahara, they use Chifkah, a special iron or copper plate to measure water quantity, to supplement hourly rotation of water.

The mechanism of Chifkah is so delicate that it distributes the little amount of water available in an extreme arid zone. The soil and historical background of these differences, incidentally, coincides with the aridity of the area. The most neglected points of study on Qanat irrigation is the role of Qanat irrigation within the scope of the whole irrigation system. In this report, the distribution alone does not represent the actual evaluation of Qanat system in the respective area. For example, Qanats around Suleimania (Iraq), Nicosia (Cyprus), and Palmyra (Syria) are now mostly ruined. But Qanats in Iran or Afghanistan, generally speaking, are still constructed and compete with artificial wells. Tehran had 35 Qanats and new potable water sources, i. e. artificial wells are replacing Qanats.

The economic evaluation of Qanat construction in conjunction with financial investment has been changing. First of all, simple and hard underground work in close connection with land tenure system (Iran) or slavery system (Sahara) have become slightly out of date. Secondly the permanent flow of Qanat water wastes the available quantity of the original sources.

Especially the water flow at the time of no agricultural products only loose the water budget. Thirdly the construction needs a lot of time and the repair and maintenance of Qanat requires of the users' free labor at least once a year. This free labor is very difficult to get nowadays and public organizations or landowners must pay a fair amount of money. Thus Qanat construction has been in decline in almost all the Qanat region. Nevertheless, a very simple technique of construction, the permanent flow of water without any mechanics, 
prevention from evaporation, almost constant temperature, and a design of conduit free from air or water pollution, and other elements are still being reevaluated.

In China, (Shing-Chi'ang) they have constructed new Kan-erh-ch'ing under the new regime of socialism; the water right is controlled by the local society instead of past landowners and so they have renewed the traditional technique for the development of the area.

In conclusion the author would make the following key points on the origin and diffusion of Qanat.

1) The origin of Qanat may be found in Central Asia, probably in Armenia or Persia.

2) The dating of the invention of this technique is obscure. The so called Achaemenid origin might be acceptable but it still needs further documentary confirmation.

3) Diffusion of Qanat into other areas besides Central Asia might be followed historically through the expansion of the Arab empires or immigration of Persian engineers. But the chronological relations between the Roman intrusion of Arabia (for example Syria) and Persian influence are not clear.

4) The adaptation of the technique in the respective area depends on the environment. In particular, the technique of water distribution is quite different from area to area and Qanat in the Sahara shows an extreme adaptability to the arid environment.

5) Water right is based on Shari'ia. In a country where the continental civil code has been used, they use the traditional Quranic law on water.

6) Generally Qanat irrigation is in decline. But modernization of construction techniques will survive the traditional techniques and in some countries Qanat is still economical.

7) Qanat, as a typical arid zone irrigation system, should be reevaluated in relation to other traditional irrigation techniques such as Serir, Shaduf or Saqiya. The distribution of these techniques, especially of Saqiya (Persian wheel), resembles the difference in distribution of Qanat techniques.

8) Hydrogeological and stratigraphical background of Qanat differs from area to area. These local modifications represent man's interesting response to the natural environment. In this paper, the author describes some examples of Qanats in Iran, Syria, Arabian Peninsula \& Egypt and gives basic data on the study of the topic. 


\section{Qanat in Iran}

\section{(i) General Remarks}

Qanats or subterranean canals are one small unit of irrigation which utilize underground water without mechanics. Qanat accepts water in the underground canal and conducts it to the surface (field). It is believed that Qanat has been used more than 2500 years in Iran, and the system of Qanat irrigation is one manifestation of the glory of the ancient civilization of Iran. In principle, Qanats are composed of three principal parts: well, gallery, and pool.

Well

Originally they dug wells of Qanats with one round section of $0.8 \mathrm{~m}-1.00 \mathrm{~m}$. Wells must be deep to let Qanat reach the nappes of aquifers. There are some Qanats of which the mother well's depth is more than $200 \mathrm{~m}$. Such wells served for the extraction of materials during the construction of Qanats and also for the ventilation of the galleries.

To prevent from entering of rain water and torrents to wells, and breaking of materials, they put round moles around the entrance of wells. Intervals between wells of Qanats varies from $20 \mathrm{~m}$ to $100 \mathrm{~m}$ and depth of wells influences the intervals of the wells. It is necessary to pay more attention to the cleaning of galleries.

\section{Gallery}

The gallery is formed of two principal parts. One part is the aquifer which penetrates the aquifer strata and drains underground water; the other is the simple conductive tunnel of underground water. It is clear that the digging of the gallery is usually rectangular and its dimension is large enough for a man to walk and work in. The width of the gallery is between $0.50-0.90 \mathrm{~m}$ and the height is between $1.0-1.5 \mathrm{~m}$. Generally the slope of the gallery is 2/1000 but around the parts where fast erosion might cause some accident, the slope is decreased to $0.5 / 1000$. In the mountain area length of gallery is short, but in the plain it is longer. The length of Qanats varies from 0.5 to $60 \mathrm{~km}$. The longest Qanats are found in Khorassan and Yazd. Usually each Qanat has one gallery but in similar topographical conditions, branch gallerys will be dug to modify the supply of water. The direction of gallery needs not be straight.

\section{Pool}

In order to reserve an amount of water supplied by Qanat, they often con- 
structed a pool or reservoir at the output of Qanat at the surface.

The exact date for the digging of the first Qanat, as this system is called in Iran, is not known, but it has been concluded from ancient books that the digging of Qanats started before the Islamic era. Nasser Khosrow in his "Book of Travels" speaks about the excavation of Gonabad Qanat in Khorassan and reckons the date of its excavation as very remote.

Goethe in his "Dates and Information on the Western and Eastern Diwan" (Annals), considers the interest of Parthians in the creation of Qanats to be a logical result of Parthians way of thinking and respect for the symbols and manifestations of power.

The number of the Qanats dug in Iran is not one or ten, or hundred or a thousand, but tens of thousands throughout the Plateau. Except in Iran, and the lands once under the sway of Iran, where underground water secured by this system has been used, no mention of Qanat has been made in any country of the world.

The length of the Qanat and the depth of the mother well (the main and last well supplying water) is very variable. It can be said that its length ranges from a hundred to tens of thousands of meters and the depth of the mother well reaches from three to several hundred meters.

The exact number of Qanats existing in Iran is not known, but according to informations compiled by the author from various sources, the number dug in Iran during the centuries amounts to 30,000. Of this number some 22,000 are in running condition and the rest, that is 8,000 , are ruined and in a dry state. If we estimate and assume the number of villages in Iran as 50,000 (no exact statistic is available) 18,000 villages receive their supply of water for irrigation from Qanats.

The total amount of water discharged by Qanats in operation is estimated to be about 40,000 sangs (560 cubic meters per second). Experience has shown that rehabilitating old Qanats which may never have been properly cleaned and repaired in many years will very greatly increase their flow, sometimes as much as eight or ten times. It is estimated that if all the ruined and dry Qanats are repaired and the operating ones cleaned, the total discharge volume of the water will be increased to about 120,000 sangs (1600 cubic meters per second). This amount of water is equal to three fourth of the average annual discharge of Nile River in Cairo and thrice the discharge of Karoun River at Ahwaz. If we calculate the average digging cost of each Qanat in Iran as one million rials, 
the total cost will amount to about 30 million rials. By taking into consideration the number of villages and towns that have been established as result to Qanats, their economical value and importance in Iran will become more evident.

Up to recent times the digging of Qanats has been done slowly by Muqqanis by means of ancient and primitive methods and tools, such as picks etc. This mode of excavation was very slow and took a long time. At times when the diggers were confronted with rock or other difficulties completion of a Qanat required several years of strenuous work.

The cross section of Qanats almost throughout the country is uniform and is such that a man of ordinary stature can pass through the underground canal easily by bending his body comfortably in a standing position. There are Qanats in Iran, where owing to the presence of rocks, completion of excavation has taken as long as three generations. At present, owing to the availability of modern mechanical equipment, the complicated problem of excavation of Qanats has been solved, so that the digging which formerly took 20 to 30 years can be achieved in less than a year.

In addition to mechanical equipment, technical principles also should be observed and taken into consideration. In order that a Qanat may reach the groundwater and bring it to the surface the main outlet tunnel must be dug up the slope of the land at a flatter slope than that of the water table. However the discharge may be increased by the addition of one or more collecting gallaries running more or less perpendicular to the slope or parallel to the watertable contours.

One of the matters which it is necessary to consider is that a Qanat should be excavated at a place where the underground has a slope. Regarding the slope of Qanat tunnels, care should be taken that the slope of tunnel in the water giving part be between $0-0.5 / 1000$ and the slope in the dry tunnel according to the situation to be from $0.5 / 1000$ up to $2 / 1000$.' The distances between the wells of Qanat is generally about 40 running meters.

Another wasy of increasing the amount of water in Qanats is by the use of deep wells and this very important subject is covered in detail in the part of deep wells.

In my opinion the unfavourable state of the Qanats in Iran is due to the following two reasons.

One, that most of the Qanats, after one or two generations become the property of several owners and this increase in the number of copartners makes the 
up keep and repair of Qanats difficult and impractical. No steps so far have been taken for the improvement of this situation.

Two, that in Iran at present fewer people with means and capital are willing to invest their money in construction of new or inrehabilitation of old Qanats. Hight rates of interest and profit lead them to invest their capital in other activities.

If this condition continues to exist, undoubtedly all the Qanats will be ruined within a century at the most and Iran will lose an amount of water equal to four times the average yearly flow of Karoun River at Ahwaz. It is to be emphasized here that the improvement of Qanats must be based on the modern scientific system.

\section{(ii) Qanat and geology}

The system of the utilization of groundwater resources by means of qanats is specially adapted to the geological structure and the natural hydro-geological circumstances of the Iranian plateau. Qanats have mainly been constructed in the mountain regions and the valleys of the plateau. In the coastal plains along the Oman Sea, the Persian Gulf and the Caspian Sea Qanats are very exceptional.

In the arid regions and in the central parts of the plateau the rivers do not carry sufficient water. Mainly the beds of temporary torrents are found and only the groundwater resources are available for the inhabitants. In these regions-Kerman, Yazd and Isfahan-the best Qanats are found. Here one can meet highly specialized Muqqani who are still capable to dig Qanats with the primitive means at their disposal, without making mistakes regarding the principles of hydro-geology or levelling. On the Iranian highland a system of alternating mountain ridges and valleys does exist, orientated from north-west to south-east. The valleys and plains are filled with alluvial and torrential deposits which came from the near mountains. One could say that the mountains of the Iranian highland are partly submerged in their own alluvium.

The infiltration water and the temporary torrents disappear in these alluvial deposits. They do form more or less extensive groundwater reserves. The groundwater table is sloping from the mountains toward the valley and the groundwater flows in the same direction. By the construction of a gallery in the longitudinal direction of the valley or plain, it is possible to intercept the groundwater flow. The depth of the groundwater table and the slope of the valley influences the length and depth of the Qanat. The Qanats are generally dug in the alluvial 
deposits of the valleys and plains. The most economical Qanats are constructed in deposits which are easily excavated with a pickaxe but are on the other hand solid enough to prevent caving of the gallery.

It is difficult to describe in a general way the hydro-geological characteristics of qanats because they change with the locality. Detailed hydro-geological studies have to be carried out in relation with the construction of Qanats in the different regions.

\section{(iii) Possibilities of Modernization}

The application of modern techniques can contribute in many ways to an improvement of the ancient system.

First of all modern hydro-geological prospecting can replace or complement the traditional experience of the Muqqani in locating the possibilities for Qanat construction. This should include trial drilling and pumping tests. Trace and slope of the Qanat can be determined with greater accuracy and deviations during construction will no longer be necessary, if modern working methods are applied. In this way the length of the gallery can be reduced, irregularities avoided and seepage-losses in the section above the groundwater table considerably decreased. Mechanized methods of excavation will also affect the number of shafts needed during construction and such influences considerably the total volume which has to be excavated. The use of pumps during construction makes it possible to work on several points at the same time in the water yielding part of the gallery as well, and in that way the duration of the work can be shortened considerably. More and better linings will reduce the need of costly repairs and safeguard a satisfactory operation. By constructing simple gates on regular distances it will be possible to remove sedimentation by means of flushing. In that case the traditional principle that even lined galleries must be big enough for a man to pass through could be discarded. The final cross-section can then become more rational and for instance concrete pipes could be used. Several of the improvements indicated above are at present tried out on new Qanats at Hamadan and Nain.

It seems advisable not to underestimate the practical experience of the Iranian Qanat-diggers. Every attempt at modernization and extension of the groundwater-utilization by means of Qanats should aim at a synthesis of the local experience of several thousands of years and the possibilities of modern techniques. 


\section{(iv) Storage of Groundwater}

Most of the existing Qanats make possible the utilization of the groundwater reserves in the superficial layers, where a free groundwater table exists. This causes strong seasonal variations in the discharge of the Qanat with often a maximum in spring and a minimum in the late autumn or winter. Especially in shallow Qanats the variation in discharge is often closely related to the seasonal variation in precipitation. As a result of this much of the water flowing from the qanat is not utilized because it does not come at the right moment. Investigations should therefore be made to determine it to what extent will be possible to close a Qanat temporarily during the period when the water is not needed. Under various circumstances this might lead to the storage of a considerable amount of groundwater. Such structures would involve measures to protect the Qanat from caving and on the other hand prevent piping at the back of the lining or along the pipes which could be used instead of linings. The eventual solution will have to very with local hydro-geological conditions. The solution seems obvious in the case where a Qanat crosses an impervious layer.

Another possibility could be to supplement the Qanat-discharges during periods of low flow, by pumping water into the Qanat from deeper layers. The depth of the qanat at the place where the pump is installed being the gain in pumping elevation. This could be done in order to exploit two water bearing strata with one combined system. It is however also possible to use such a combination in relation with the seasonal storage of groundwater by lowering the groundwater table extra deep during the period of maximum water need and have the so created shortage refilled during the period when the Qanat formerly did give superfluous discharges.

This ideas outlined above certainly do not pretend to be more than a rough outline of what might be possible. Thorough investigations should be made before they can even be tried.

(v) Qanats in comparison with other groundwater utilization

The most important possibilities for the utilization of groundwater resources are:

Shallow wells from which the water is often lifted with oxen; only possible when the groundwater table is comparatively shallow. For Qanats, no lifting is needed and therefore no costs of operation. They utilize in general deeper groundwater layers than is possible with the first method; a considerable slope 
of the terrain is needed, therefore impossible or difficult in flat plains.

Pumped wells can utilize much deeper groundwater layers as a result of modern techniques of drilling and pump-construction. Careful maintenance and considerable operational costs are involved.

Buried cutotts-in order to bring a well defined groundwater flow to the surface. They are only possible under very special hydro-geological conditions, for instance when (buried) river valleys are crossing some narrow ridge of impervious rock.

It is evident that it is impossible to give one method preference over the other ones in general, because their applicability is directly related to special circumstances. In ancient times mainly the first two methods were developed. The Qanat system was especially developed under the Iranian conditions of relatively deep groundwater tables and sloping foot-hills of the many mountain ridges, which traverse the Iranian highland. The disadvantage of both ancient systems is their high sensibility for over yearly periods of drought. The lack of operational costs and the relatively small maintenance needed for a well constructed and modernized qanat are positive advantages.

The modern possibilities of pumped wells have practically overcome the sensibility for periods of drought. The other side of the picture, however, is that they can lead to serious overpumping and exhaustion of the groundwater reserves. A pumped well not only requires considerable costs of operation, but also a very careful maintenance. The latter is mainly a question of organization, but it is exactly this point which has led to many disappointments in countries which in technical aspect are underdeveloped. The cost of the water per $1 / \mathrm{sec}$. of a normal qanat is considerably smaller than for a small pumped well of the same production, (30 1/sec.) For a well of greater capacity the cost of the water becomes far less. With $150 \mathrm{l} / \mathrm{sec}$. it has dropped to somewhat beneath the cost of Qanat water.

As explained before, a combination of Qanat and pumped well might be very advantageous. The question to what extent the physical conditions in Iran are favorable for the construction of new modernized qanat should be included in hydro-geological studies.

(vi) Waterlaws in relation with Qanats

Accordint to Miss Lambton the practices related to Qanats probably go back in part to pre-islamic times. The local customs are still the basis for an impor- 
tant part of the practices. In the books on fiqh (law) and in the Traditions of the Prophet nothing was mentioned about Qanats. For this reason a Governer of Khurasan in the ninth century A. D. seems to have assembled "all jurists" to write a book on the Laws of Kariz (Qanats). This book, the Kitabi Qani, existed in the eleventh century.

The Qanats are mentioned in several places in the Civil Code and the Law of 6 Shahrivar 1309 (28 Aug. 1930) is clearly designed to encourage the construction of Qanats. By the Law of 29 Urdi Bihesht 1322 (1943) the Independent Irrigation Corporation was established and was given the supervision of all matters connected with irrigation in the country.

Of particular importance is the Law concerning harim - a reserved area around a landed property, qanat, canal, etc... (art. 136/139 of the Civil Code). On both sides of a qanat an area is reserved of 500 gaz (about 500 meters) on soft ground and of 250 gaz on hard ground. In each case it may be increased whenever it appears necessary to avoid damage. In this way the rights of the owner of the Qanat are guaranteed. Because there are an enormous number of Qanats, however, and the generally utilize "superficial" groundwater resources, at the same time the possibility of the utilization of eventual deeper groundwater layers under the reserved areas is cut off.

The division of the Qanat water is often very complicated and sometimes goes back to very old rules. Miss Lambton gives an example of a Qanat which had more than 10,000 shares, divided among several hundred owners. In Ardistan (Yazd region) the division of the water, according to local tradition, goes back to Hulagu, the grandson of Chinghiz Khan. In the Isfahan region the water division is said to date from the time of Shah Abbas (1600 A. D.).

\section{(viii) Some Examples of Qanats in Iran}

\section{Yazd}

Yazd is one of the most concentrated and typical Qanat irrigated areas, like Kerman. The population is about 80,000 (1956). The city lies in the very heart of the arid basin and there are no rivers. The cupola type roof and wind tower to reduce the hot desert wind remind us of the medieval Yazd as described by Marco Polo. Masjid Jameh had one of the most beautiful minarets which the author has ever observed in all of Iran. The city itself has an old quarter like a labyrinth and the colors of the dry bricks show us a typical city in arid land. The altitude of the city is $1220 \mathrm{~m}$ and the annual precipitation is $126 \mathrm{~mm}$. 
According to Mr. Hossein Ali Mahummadi, an engineer of the city hall of Yazd, there are about 1000 Qanats around Yazd. Mr. Mahummadi himself is a Muqqani who is a professional hydrogeologist in a modern scientific sense. Muqqani is one of the most honoured professions in Iran, and Yazd is a famous place to send Muqqanis all over Iran for Qanat construction. To construct Qanat, at first Muqqani looks for a suitable aquifer.

Usually they dig a mother well (Madar Cha) in an area remote from the prospective sttlement and every 30 to $40 \mathrm{~m}$ they dig ventilation shafts for each approximately $2000 \mathrm{~m}^{2}$. The underground tunnel connects horizontally the bottom of each ventilation shaft.

The section of underground tunnel is oval ( $1.00 \mathrm{~m} \times 0.70 \mathrm{~m}$, for example) and it seems fairly hard for a man to work in the tunnel. Around the entrance of the shaft, a kind of mole hills are formed. In Yazd, they have covered holes by bricks or stones since the 13th century to prevent accidents of children. The accident (childrens' falling down into wells) is very rare.

The Qanat which the author has observed has a length of $42 \mathrm{~km}$. The mother well (first well or first ventilation shaft) has a depth of $120 \mathrm{~m}$. The shaft reaches the water table at $55 \mathrm{~m}$ and from the table penetrates downwards another $65 \mathrm{~m}$. Each shaft could irrigate $5000 \mathrm{~m}^{2}$, but the water quantity will be reduced to $3000 \mathrm{~m}^{2}$ on the surface.

To dig those shafts, they use wood pulley (Charch-Chaha) which is a universally used lift to move workers and materials up and down. Other tools are very simple ones; buckets made of used tyres (Galeh), shovels and picks. Galeh was made of sheep skin in old times. The workers go down into the shaft after binding themselves by ropes to the Charch-chaha, and dig the tunnels by pick and send up buckets of mud by the rope of Charch-chaha. Ususally they work all day underground except for lunch time when they are brought up by the rope of Charch-chaha to the aurface. Generally, the manoeuvers are quite similar to those of mine workers and very monotous. Such work is often dangerous. The rope may break. Stones may fall down from the entrance of the shaft. Air circulation is very poor in the tunnel and workers may be suffocated. Sometimes they were bitten by snakes dropping from the surface into the water. Although it may seem very strange, they may be drowned by torrents after the connecting of two shafts. Workers do not dig shafts after they have had a nightmare or a disagreeable feeling. This way of thinking is also similar to that of mine workers.

The cost of Qanat construction is paid by the landowner. For example, 
if the landowner digs one shaft (Cha) of $90 \mathrm{~m}$ he pays 50 rials for unskilled workers and 70 rials for Muqqani. Usually they dig $3 \mathrm{~m}$ per day and a $90 \mathrm{~m}$ shaft will require one month of digging. Thus it is not a rare case to dig Qanat for 6 months or one year; especially the digging of the deepest well (mother well) is very hard work. In Yazd, within the semidiameter of $500 \mathrm{~m}$ from the existent Qanat, no new Qanat construction is permitted. All Qanats must be registered. There is therefore no fluctuation of water quantity.

The legal water right of Qanat is owned by the landowner, and sometimes shared by several. Very often the owner of the land irrigated by the Qanat and the landowners overlap each other. Generally, Qanat water is free of charge for drinking. The cost of water for irrigation must be paid to the owner of Qanat in proportion to their own Qanat irrigated land. The contracts are drawn up on the understanding that the cost will be paid in crops or labor. Any cut off of Qanat water would mean the death of daily life in Yazd. Severe contracts may be accepted, but poor peasants sometimes steal water in the night.

The principle of distribution of water is on an hourly basis. The general features of water distribution are quite similar to the hourly rotation of irrigation water to the paddy fields in Japan.

\section{Qom}

Qom is the holy place of Shi'ia sect of Islam where the Mosque Fatimah attracts many pilgrims from all over Iran. The altitude is $940 \mathrm{~m}$ and annual precipitation is about $98 \mathrm{~mm}$.

Water supply to Qom depends on Rud Qom (Qom River) and Qanats. The water quantity of Rud Qom is so small that the water of Qanat is an important source for the inhabitants. Jamkaran dehe, southeast of Qom, has about 350 families. There is an old castle ruin (by oral tradition about 1500 years old) and dehe may be forty years old, but no historical documents are available. The water to dehe comes from seven branches of Rud Qom and the total water quantity is 32000 units.

$\begin{array}{ll}\text { 1. Kandeh } & 800 \text { small Qanat } \\ \text { 2. Baravastan } & 3300 \\ \text { 3. Karadj } & 1300 \text { small Qanat 8 wells } \\ \text { 4. Shansabad } & 2800 \\ \text { 5. Jamkaran } & 3700 \\ \text { 6. Shahratan } & 4400 \\ \text { 7. Darwazeh Galeh } & 2300\end{array}$


No. 1. Kandeh is owned by Mr. Triacci who is the representative of followers of Fatimah Mosque and ex-mayor of Qom. He has a beautiful fruit garden irrigated by Qanat of Kandeh. The owner of the water rights is called "Mirab." Mirab does not usually live in the respective village, but stays in cities such as Tehran.

In Case of No. 5. Jamkaran, a representative of Dehe consults with the agricultural section of the city hall and after their recognition they discuss with Mirab. The final decision of water distribution is decided by city hall and Mirab. In summer when water is so settled, water comes to the village after five day's use of it by the village on the uppersteam. Then it takes 2 days to reach Jamkaran. The distribution of water to the whole field takes 5 days. The 12 days difference from the uppersteam village is not very good for the vegetables and wheat.

Near the village there is a well $320 \mathrm{~m}$ in depth. The inhabitants of the village drink a little saline water from the river. Agricultural products here include crops such as wheat or rye and vegetables such as tomatoes or eggplants. They use cows for cultivation and have donkeys and sheep. Generally they are engaged in pastoral nomadism in summer and cultivate rice or wheat in winter. Each family has from 10-15 to $150-200$ cows.

The land tenure system of the village is very simple. One tenth of the total area, i. e. $160 \mathrm{ha}$, is cultivated land and the other part is uncultivated. The cultivated land is divided into parcels of 20 ha. The peasants take $1 / 4$ of the products and $A r b a b$, landowner, takes 3/4. The peasants have their own homes, but domestic animals, seeds and agricultural tools are sponsored by the landowner. Arbab is called Ryat in Arabic and Degnan in Persian. In water-short summers, peasants go to Tehran for supplementary work or to Kashan where they have a chance for roadconstruction work (80-90 rials per day) and in winter come back to the village to cultivate winter crops, such as sheat.

\section{Azerbaijan}

In Iranian Azerbaijan, there are some Qanats on the lakeside of Urmia and its southern part, Kurdistan. The following example is a case study on a small dehe named Karijibad.

Karijibad is about $50 \mathrm{~km}$ west of Maraga. The road to Maraga is very rough, even for a Jeep. The population is about 450, with 100 families. The inhabitants are pure Azerbaijani and they speak native Azerbaijan language. At Sarguizen, east of the village, lives Mr. Esmail Khan Sedghy, who owns one- 
half of the land of the village. Another quarter of the land is owned by $\mathrm{Mr}$. Birna, Maraga, and the other quarter is owned by Captain Mostofi, Tehran. Mr. Sedghy bought the land about 30 years ago, built the village and was still planning to make a new village. He himself has the experience of Qanat construction. He declared resitance to communism when the commander of Azerbaijan Peoples Republic came to the village just after World War II and received three honorary medals from the Central Government of Tehran. This episode tells us something of the background of the landowners who dig Qanat, control water and established the autonomy of the village. Perhaps Qanat was introduced to Azerbaijan by Iranians and the role of Qanat in the semi-arid regions where dry farming is dominant is fairly important.

\section{Kanayets in Syria}

The subterranean drainage which uses higher level infiltration water to flowe towards lowe levels is one of the most advanced engineering and very fluctuating hydraulic techniques in arid lands.

This is not peculiar to Syria. We find it in Cyprus, in Iraq (Karez), in Iran (Qanat) in Turkestan (Kariz) in Morocco (Guttaras of Houaz and Sous) and in Algerian Sahara (Fegaguir or foggaras). There are surely very old, but their origin is obscure. Some believe they have a Babylonain origin and others a Persian origin. It is sure that most of Kanayets are the work of Romans. Very often in Syria, they are called "Kanayets Roumanies." Besides those Kanayets Roumanies. various types of Kanayets show various origins. Probably the areas have utilized this system, and actually the inhabitants have dug new Kanayets in the Ghouta of Damascus, for example. Kanayet of Oum-el'Omi in Palmyra is a veritable architectural work. The principal canalization is ca. $2.50 \mathrm{~m} \times 0.80 \mathrm{~m}$, completely constructed by stones, including nine steps of marble and the entrance gate with sculptured arcade. The gallerys are generally rectangular in section. The Kanayet of Amsareddi also has a section of $0.8 \mathrm{~m} \times 1.60 \mathrm{~m}$ because the Kanayet traverses a hard chalky bed and it is not bricked. Only one section of $0.60 \mathrm{~m} \times 0.90 \mathrm{~m}$ in the friable alluvial bed needs cement or stones. The section of gallerys is very complicated, especially the ones which are simply dug in the light soil as in the case of Ghouta. The subterranean conduit is dug in the shape of a spinning top. This special form is useful for the prevention of abrasion and erosion. The lower part refills gravels and soils. 
The egg-shaped upper part is filled during floods. All Kanayets are not a simple canalization which terminates in the open air in the accumulation basin. It is possible to dig one or many underground basin-reservoirs under the shaft of the conduit, and from there they obtain water by various kinds of pumping. Some Kanayets are completely underground and constitute one unique underground terminal basin from where a series of underground basins start and underground water is brought up by chains or in other ways. Kanayets are still used in Ghouta, Qalamoum (Jerud, En Nebk etc.), Homs (El Qaryatein, Palmyra), Hama (Selemiya), Aleppo (El Bab, Membij). (Fig. 1) But numerous canalizations of Kanayets have been abandoned because of sand sedimentation. Although they dig new Kanayets, the restoration of used Kanayets is usually considered to be fairly uneconomical.

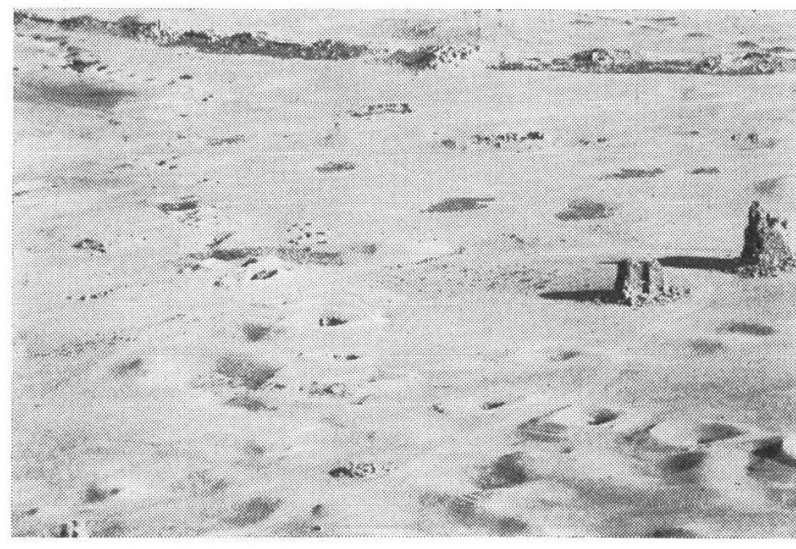

Fig. 1 Chains of Qanats in Palmyra taken from the top of Qasr el Arab.

\section{Arak}

Arak is a small village about $40 \mathrm{~km}$ east of Palmyra and is composed of 22 families of 200 inhabitants.

There are three Kanayet called Kanayet al-sharki, Kanayet al-Garbi and Kanayet Wasai. According to Mahmoud Alaoui Saoud, 70 years old, he recognized the existence of Kanayet when he was born. He still remembers cleaning Kanayet when he was 11 years old. Bedouins came and dropped and in the wells and it was necessary to reclean Kanayets. Nowadays water from Kanayet is distributed for 8 hours per for day for five days to each family. They cultivate apples, olives, granada, dates, figs and grapes.

Kanayets are dug in the sandy gravel alluvial beds and curiously in some well we find many neolithic or mesolithic materials. These interesting pheno- 


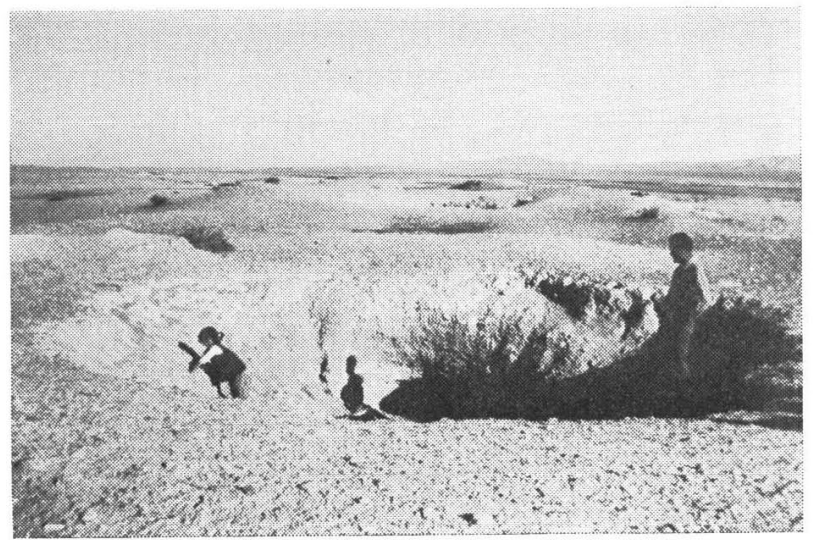

Fig. 2 (a) Fujjara in Arak, General View of Fujjara.

mena are found not only in Arak, but also in Taibe and Qom. It may be difficult to think about a neolithic or mesolithic origin of those Kanayets, but at least Arak might have been dropped down when they dug Kanayet, possibly in the Roman age. (Fig. 2).

No documentary confirmation is available, but the trade route between Palmyra, Mesopotamia and Persia, over the Syrian Desert and the Euphrates might facilitate direct or indirect Persian engineering's introduction to the Palmyra region. To confirm the history of Kanayet in Palmyra and Arak, systematic excavations would be necessary.

Fig. 2 (b) Fujjara in Arak, Entrance to the undergioundwater tunnel.

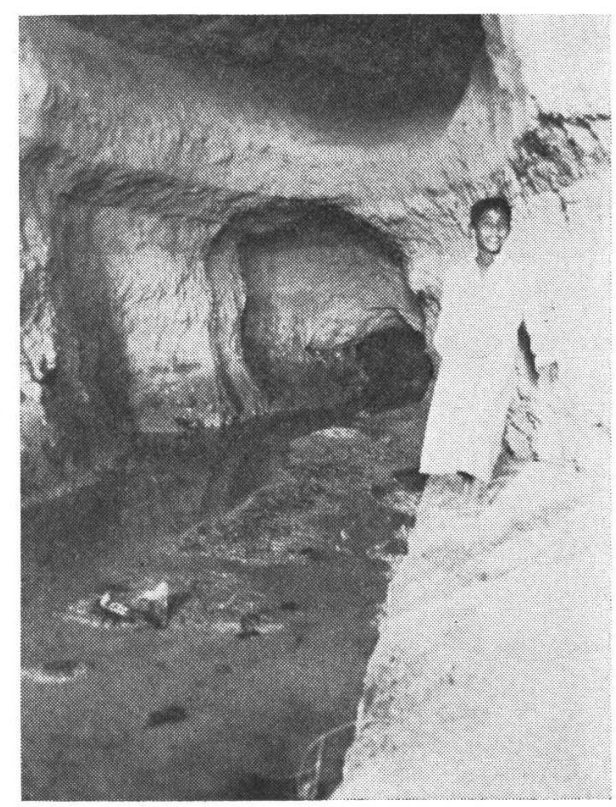




\section{(i) General Remarks}

\section{Qanat or Underground Aqueducts in the Arabian Peninsula and Egypt}

An ancient example of them has been found in Baharia oasis (Egypt) and was proved to be made in ancient Egyptian times for a chamber in a tomb of that period was proved to have been shifted to avoid interfering with the aqueduct, but the Persians used them extensively and have introduced them in Arabia in the beginning of Islam when vast riches poured into the country. Hardly any wadi has been left without its "doubles", and one must guard against their presence when building dams in these valleys for they will undermine them in flood. The beds of wadis are sandy and even gravelly and during floods a big percentage of it infiltrates into the bed and runs slowly. Opinions differ on the travel of subterranean water and experiments on this subject are much needed. In the Hijaz, the wadis run in igneous rocks which are like cast iron in their retention of this water and lie generally from 10-15 $\mathrm{m}$ below the surface of the bed. Its top, two metres, is fissured by the dissolving action of water and is the source of water in the wells. This water is collected in the gallery and run at a flatter slope than the bed of the wadi. Generally, the slope of the bed of the wadi is 6/1000 and the aqueduct runs at $1 \sim 0.5 / 1000$ and as the ground water is $8-10 \mathrm{~m}$ below the bed, so the aqueduct after running $1.5-2.0 \mathrm{~km}$ runs free flow on the ground and irrigates the berms of the wadi which are safe from the torrents and to guard against reosion they are protected by stone walls (Zatilh) and the garden is called (Hif pl Hiyf). The famous palmeries of Medina lying to the north of the town and west of Ohod mountain are a good example and are fed by the subsoil waters of Wadi el Aqiq, but now they suffer from the lowering of the water table for to the south of Medina the gardens have been irrigated by wells worked by animals, but now oil engines and pumps have been widely used and laws should be issued preventing the ruthless installation of these pumps.

There are laws in existence all over Arabia. This law is called ('Alf) and the most elaborate is that of al Ula north of Medina and near Madain Saleh where the Nabateans left their ruins, thus through the ages the art of water control has persisted.

The famous Zobeida aqueduct which feeds Mecca with water was started by Queen Zobeida, wife of Harun al Rasheed. In the early Islamic period the pilgrims drank from twelve wells of which the famous well in the $\mathrm{Ka}$ 'ba was one, 
but when Islam spread, these wells were insufficient for the pilgrims and water had to be carried from far and sold at extravagant prices. The aqueduct starts in Wadi No'man more than $22 \mathrm{~km}$ from Mecca and its water is dammed by a natural underground dam just east of Arafat. For this reason it is not much affected by years of drought. The inspection chambers at its source are the $35 \mathrm{~m}$ deep.

The water supply of Mersa Matruh (Egypt) depends on the old aqueduct in the oolitic limestone to the west of the town. The rain water that falls on the plain floats on the salt water and flows to the sea. The aqueduct intercepts in and if pumping is excessive and the supply of fresh water is less than the demand, salt water is pumped.

\section{(ii) Al-Kharj and Buraimi}

In the oasis of Al-Kharj, $150 \mathrm{~km}$ southeast of Riyadh, we find Qanat system which has been abandoned 7 to 8 years ago. One example, Farzan Mayyah Majra, which was investigated by the author, is about $9 \mathrm{~km}$ in length. The type of ventilation shaft is exactly same as foggara in the Sahara or Qanat in Iran. (Fig. 3) The diameter of the well is from ca. $3 \mathrm{~m}$ to $8 \mathrm{~m}$. The depth of the shaft around the village is not more than $10 \mathrm{~m}$. After the construction of 3 deep wells

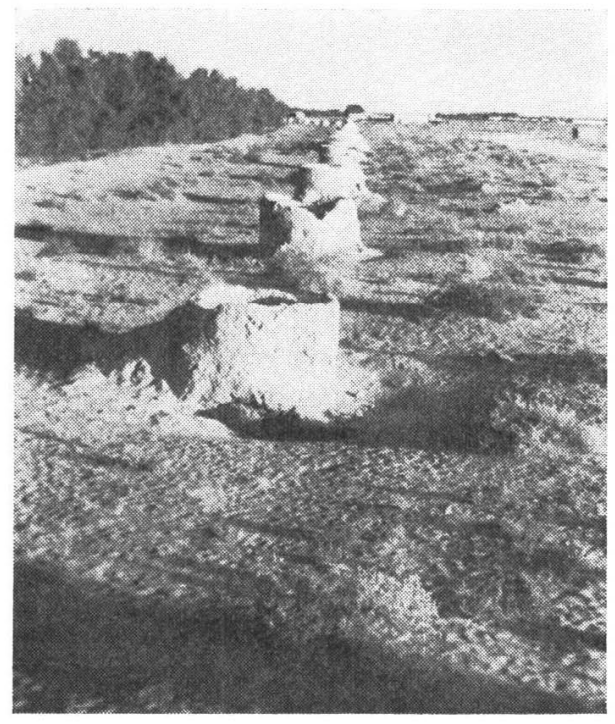

Fig. 3 (a) Chain of Wells around the garden of Al-Kharj.

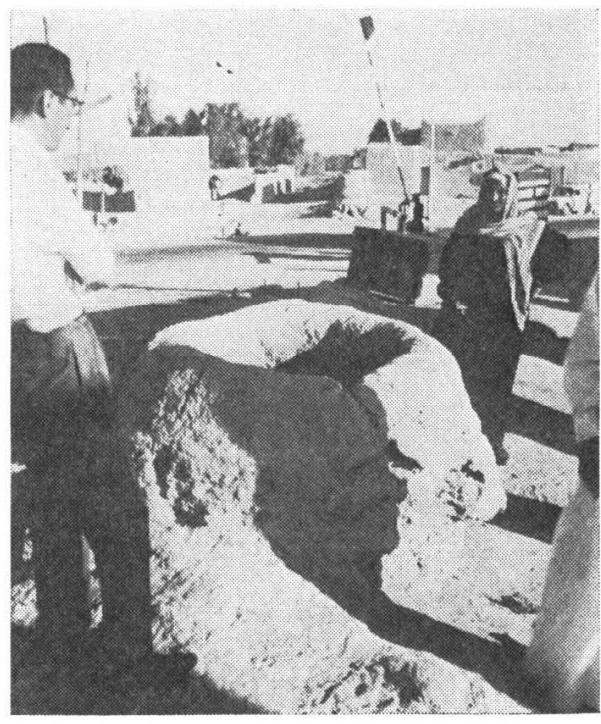

Fig. 3 (b) Qanat in the town Al-Kharj. 
by pump, Qanats have not been used there. In the oasis of Qatif, $100 \mathrm{~km}$ north of Ad Damman, we find sand buried ruins of Qanat. Those ones were used until 30 years ago, but are now completely replaced by deep wells. In South Arabia there are other Qanats north of Jiddah. They are on the foothills of the coastal mountains and the length is not so long (about 2 to $4 \mathrm{~km}$ ). The origin of those Qanats is not known, but it might be possible to think that pilgrims from Persia had constructed this irrigation system in the very spot quite similar to Elbruz or Zagros mountains foothills.

Gencrally speaking, these Qanats have been replaced by deep artificial wells and the construction of a New Desalination plant, especially in the city

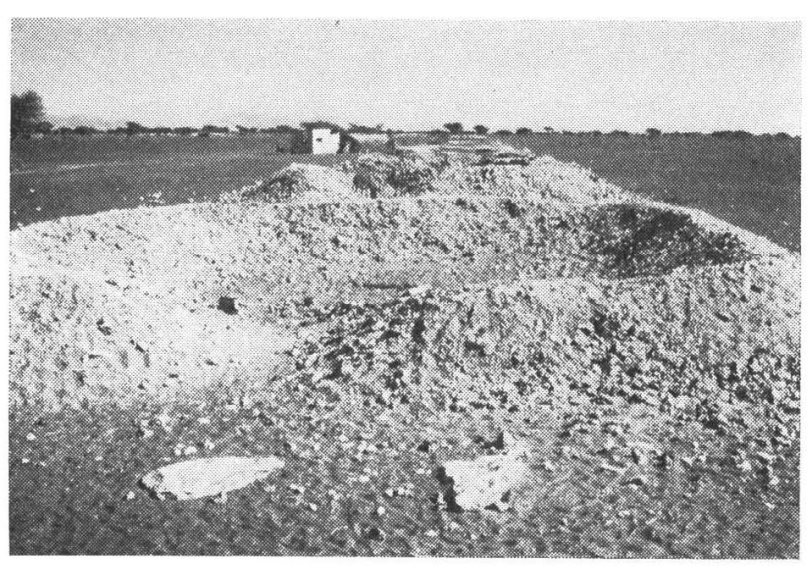

Fig. 4 Aflaj in Buraimi Oasis (EL AIN),

(a) General View of Chains of Wells.

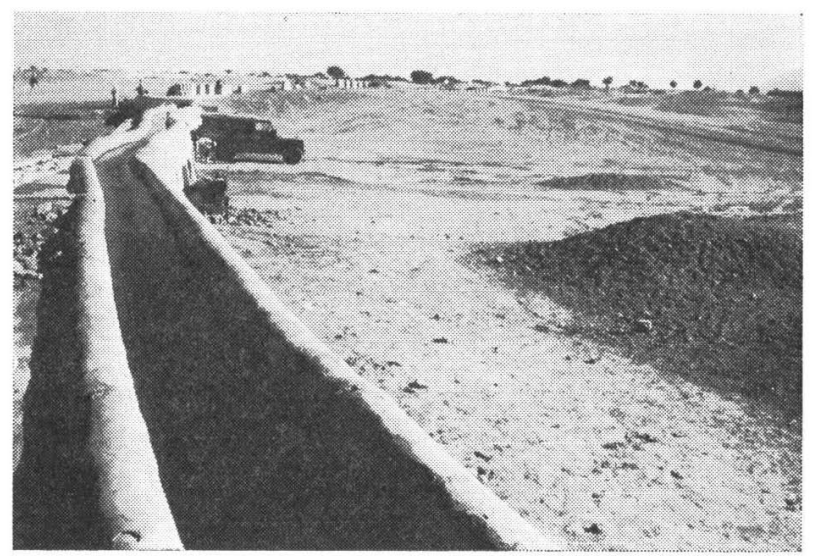

(b) Modernized Cemented Wells and Conduict. area, will replace the old irrigation system.

In the southwest corner of the Arabian Peninsula, we find Qanat system in Yemen. But these are only remains and no concrete study or documents are available. Because of the fairly rich amount of precipitation, they have constructed reservoirs and one of the most famous ones is Marib dam near San'a.

In the eastern coast of South Arabia, there are still active Qanats called Al-Falaj. Especially in the Buraimi oasis in the frontier of Muscat Oman, South Arabia and Abu Dhabi. Their techniques seem to have been introduced by 


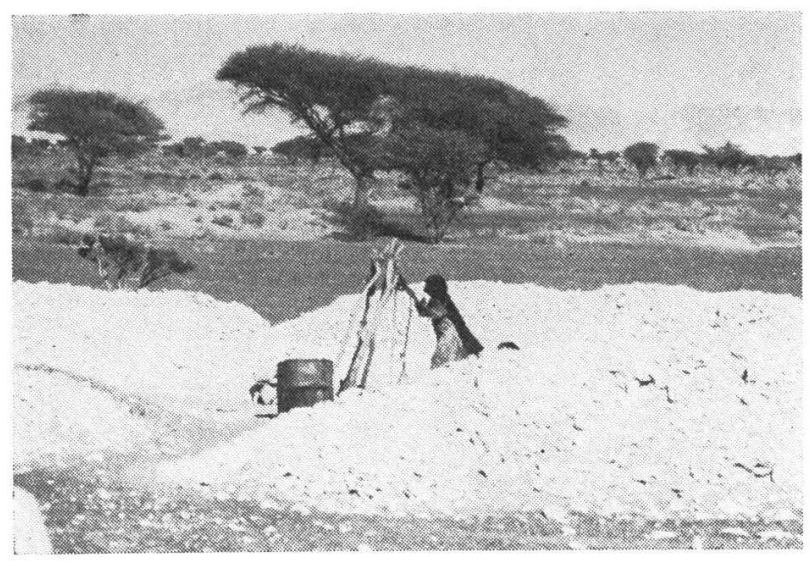

(c) Lifting Water from Falaj.

the hand of Persian engineers who immigrated in the old times. In the Buraimi oasis, there is a unique tribe which is specialized as well-diggers. Their technique is exactly same as in Iran, and sometimes they use simpler tools. (For example, they use baskets made of date-palm leaves instead of buckets made of sheep skin or used rubber). These Al-Falaj were constructed by Sheikh Zai'd of Abu Dhabi and usually they use the water for their own garden. The conduit under ground is covered by stones for some distance and the output to the surface and reservoir is constructed by stones. The distribution of water in the garden is done by the hour and many small dykes are made. (Fig. 4)

\section{(iii) Bahariya and Farafra}

Bahariya oasis is composed of Bawiti, Mandisha, Zabu, El Qasr, El Harra, Gafara, El Heiz, El Gharabuja, Tab Limun and El Ris.

The irrigation started from local Manaur. (Fig. 5) The so-called pre-Roman and Rcman wells (including ruins) are found around the oases and they number approximately 2000 .

$\begin{array}{lll}\text { Dates } & 85,000-86,000 & \begin{array}{l}\text { Mainly for local food and plus cash crops. } \\ \text { Olives }\end{array} \\ 14,000 & \begin{array}{l}\text { Interplanted in date gardens, mainly } \\ \text { for export. } \\ \text { Interplanted in date gardens, mainly } \\ \text { for local use. }\end{array} \\ \text { Apricots } & 4,000 & \end{array}$

Some Oranges, Lemons and Grapes are also interplanted in the same garden.

$\begin{array}{lll}\text { Rice } & 450 \text { feddan } & \begin{array}{l}\text { Decreasing because of the shortage of } \\ \text { water. }\end{array} \\ \text { Wheat } & 100 \text { feddan } & \begin{array}{l}\text { Mainly for local use. } \\ \text { Berseem }\end{array} \\ 100 \text { feddan } & \text { Local use. }\end{array}$

Total amount of land used for growing vegetable (onions, tomatoes, beans, 


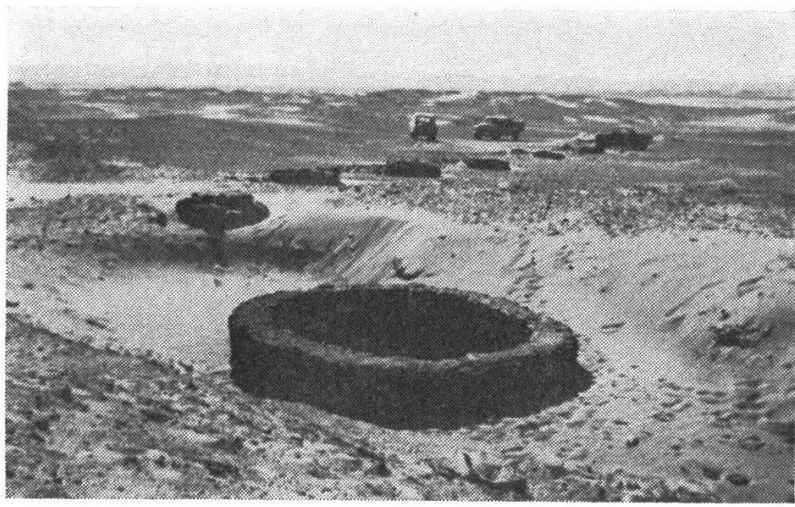

Fig. 5 (a) Manaur in Bahariya Oasis.

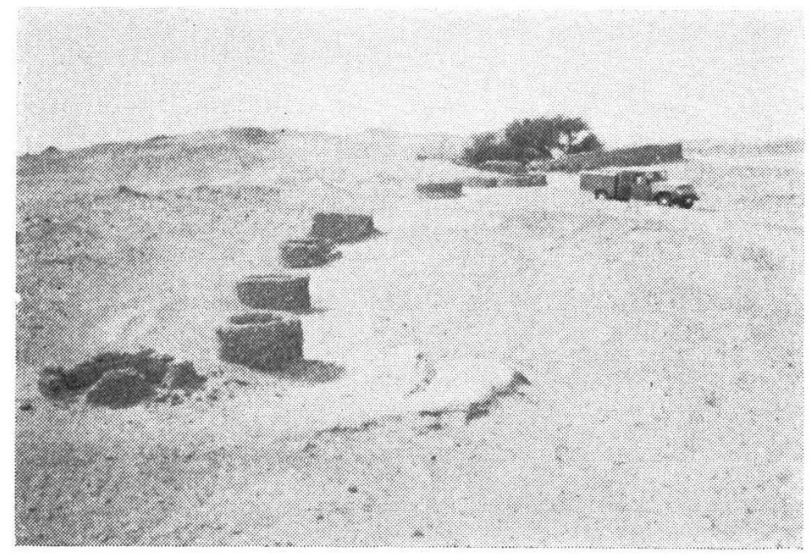

(b) Manaur in Kharga Oasis. okras, and melons) is 2530 feddan. Many feddans of land are used for pastures (alfalfa, taifa and camel thorn). This pasture land is not irrigated but very close to the nappe of the underground water. Natural vegetation is relatively sparse and its presence is a good indicator of a high non-saline (or slightly saline) groundwater table. Olives and appricots are irrigated every ten or twelve days; sorghum, wheat and berseem crops are irrigated more frequently, all of the water comes from wells, most of which are shallow and flowing. Only a few wells are being pumped. The principal tool used by the farmer is the heavy hoe or pick (fas), used for nearly all local preparation and cultivation. No animal-drawn implements are used. No chemical fertilizer and very little organic fertilizer is employed. Farafra oasis is composed of many shallow wells and about 30 small oasis. The largest of these are located at the village of Qasr Farfra and at Ain Ebsai. Abandoned cultivated lands from the time of the pre-Roman or Roman age are found near the oasis. The inhabitants now number about 950 and 75 to 90 feddans are cultivated.

$\begin{array}{lrl}\text { Dates } & 1700 & \text { Main cash crop. } \\ \text { Olives } & 300 & \text { Cash crop and local use. } \\ \text { Apricots } & 200 & \text { Cash crop and local use. } \\ \text { Citrus } & 350 & \text { Orange, sweet and sour lemons and a few }\end{array}$


mandarin oranges and a few grapes (for wine) are planted in privet gardens.

Wheat 30-35 feddan local use. one feddan will procuse $600 \mathrm{~kg}$ (wheat) or $750 \mathrm{~kg}$ (barley)

Barley

Sorghum

Berseem

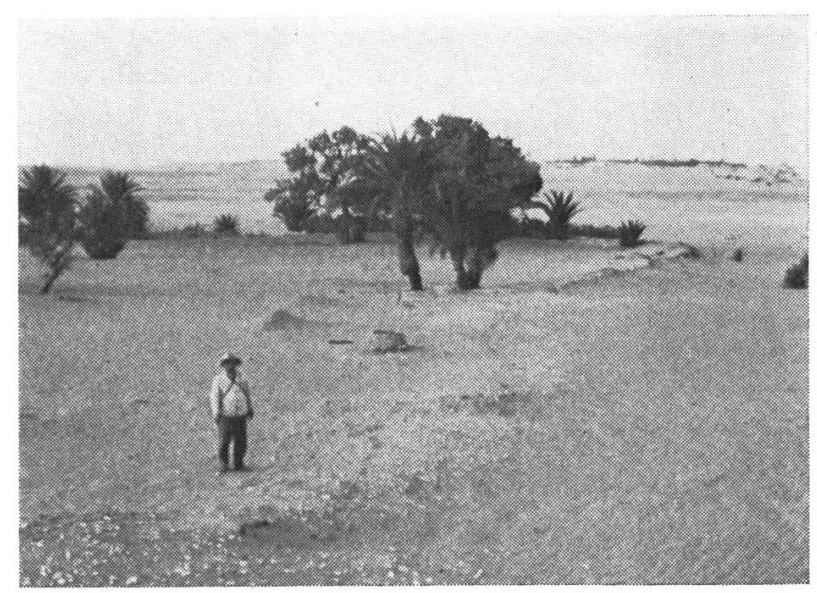

Fig. 6 Manaur in Farafra (See the Center Well).

5 feddan Very little.

20-25 feddan will procuce about $450 \mathrm{~kg}$.

Pasture areas small plot of alfalfa, taifa and camel thorn. These pastures are not irrigated and get their moisture for the underlying water table. Vegetables (beans, onions, okra, squash, eggplant and sweet melons) are planted in the small gardens. There are no cows, but only a few camels, donkeys, sheep, goats, and poultry. The tools for agriculture are picks and hoes. No chemical fertilizer is used, but a little organic fertilizer is used. In many places sand is carried to the garden to mix with the clay soil, making it easier to cultivate. Forty shallow wells are used for irrigation and new and deeper wells must be doubled. Abandoned foggara are still partially used. (Fig. 6)

The chronological sequence of the foggara in the Farafra is very difficult, but the dating might be parallel to Bahariya. The existence of a nearby caravan route crossing Bahariya, Farafra, Dakhla and El Kharga, referred to in the Roman chronicles, is fairly suggestive for the diffusion of Foggara from the fosse where the pre-Roman technique might have been introduced.

\section{(iv) Om-Dabadib}

There are very few reports on Om-Dabadib. Up to 1960, in the settlement of Om-Dabadib, the northern part of the El Kharga depression, there was cultivated land (mainly dates) irrigated by Qanat. The first well (alt. $80 \mathrm{~m}$ ) is $30 \mathrm{~m}$ deep (to the water table) and the cultivated land lies at an altitude of about $50 \mathrm{~m}$. 


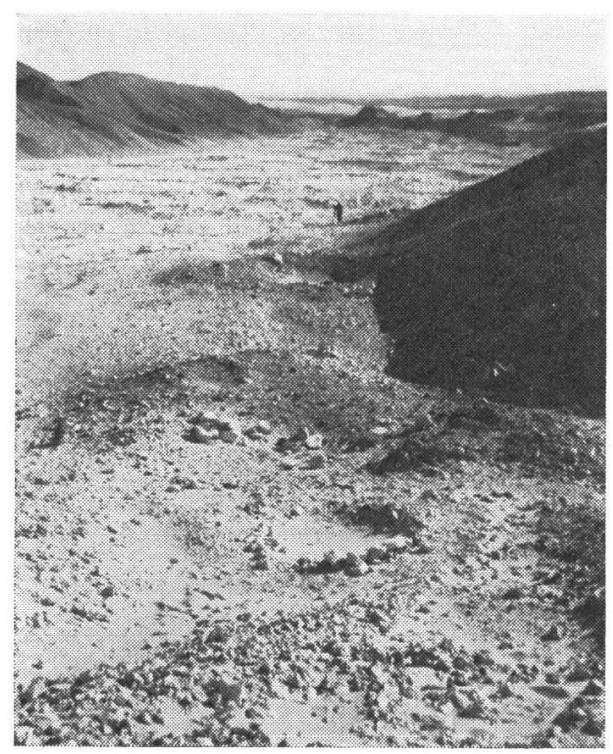

Fig. 7 Valley of Om-Dabadib and ruins of Qanat.
In the flood plain of gravels (10 to $13 \mathrm{~m}$ in width) there are much winderoded limestone and we find ventilators $(10$ to $15 \mathrm{~m}$ ) on the bank of the wadi. By the suthor's observation, the total length might be 5 to $7 \mathrm{~km}$. (Fig. 7)

A long one is to be found around the Om-Dabadib. The tunnel is connected to the edge of the desert's cultivated land and nearby we find the Roman ruin of El Qasr. The sand-buried ruins around the settlement are also very conspicuous. The existence of clayey soil shows us the past prosperous Qanat irrigation system of the area. Om-Dabadib is more similar to foggara in Tamanrasset in the Sahara. 